American Journal of Agricultural and Biological Sciences 3 (3): 522-525, 2008

ISSN 1557-4989

(C) 2008 Science Publications

\title{
Recent Sedimentation Rate and Sediment Ages Determination of Kemaman-Chukai Mangrove Forest, Terengganu, Malaysia
}

\author{
B.Y. Kamaruzzaman and M.C. Ong \\ Institute of Oceanography and Maritime Studies, International Islamic University Malaysia (IIUM), \\ Jalan Istana, Bandar Indera Mahkota, 25200 Kuantan, Pahang, Malaysia
}

\begin{abstract}
Two $20 \mathrm{~cm}$ sediment cores were collected with a D-section corer in the Kemaman-Chukai mangrove forest and analyzed for ${ }^{210} \mathrm{~Pb}$ ex (excess ${ }^{210} \mathrm{~Pb}$ ) in order to understand the sedimentation pattern. The activities of ${ }^{210} \mathrm{~Pb}$ along with the ${ }^{208} \mathrm{Po}$ tracer were measured by Alpha Spectrometry on a silicon surface barrier detector connected to a multi channel analyzer. Sedimentation rates were determined applying ${ }^{210} \mathrm{~Pb}$ dating method and found to vary between $0.94-1.11 \mathrm{~cm}$ year ${ }^{-1}$. The highest accumulation rates were recorded near the river mouth and the lowest rates at the downstream. Assuming that the sedimentation rate values are accurate, this implies that the sediments in the upper $100 \mathrm{~cm}$ at Kemaman-Chukai mangrove forest were deposited during the past 90 years ago.
\end{abstract}

Key words: mangrove forest, sedimentation rate, sediment age, ${ }^{210} \mathrm{~Pb}$

\section{INTRODUCTION}

Mangrove forests are a buffer zone between the coast and the ocean. One of their presumed important functions is to provide a mechanism for trapping sediment. In terms of their biological and chemical aspects, mangrove forests are highly productive source of organic matter, from which there is a net outwelling of energy that supports the complex estuarine and nearshore food web. Geologists, on the other hand, view mangroves as sediment sinks, characterized by long-term import of sediments as indicated by the substantial accretion of recent sediments, which underlie mangrove forests and adjacent coastal plains ${ }^{[1]}$. Physically, by virture of being in the intertidal areas, they can act as a recorder of environmental changes via sedimentological characteristics and in the preservation of spores and pollens.

Despite the acceptance that mangrove ecosystems are important sinks for sediments, few studies have addressed sediment accretion in this environment. Several authors ${ }^{[2,3]}$ have studied some aspects of the sedimentology of mangroves and quote different sedimentation rates, which is probably a reflection of the non-representative sampling techniques employed. Spencely ${ }^{[4]}$ and Shahbuddin et al ${ }^{[5]}$ have introduced a simple method for measuring accretion by simulating pneumatophores using rods and stakes and an artificial horizon marker method, respectively. Meanwhile, long- term accretion rates using radionuclides have been well documented $\mathrm{d}^{[6-8]}$ but use of this approach has been not many published ${ }^{[5,9]}$ and limited in the mangrove ecosystems. In the present study, we use ${ }^{210} \mathrm{~Pb}$ to estimate sediment accretion rates.

The concentration of ${ }^{210} \mathrm{~Pb}$ within sediment is governed by processes such as source input from overlying waters through sedimentation, in situ production and radioactive decay. Many scientists have successfully demonstrated ${ }^{210} \mathrm{~Pb}$ as a sensitive tracer for understanding the geochemical changes which have occurred during the century in different ecosystems, including coastal marine sediment, due to industrialization. ${ }^{210} \mathrm{~Pb}$ has proved to be a valuable tracer of sediment mixing and accumulation in a variety of environments ${ }^{[3,6,7,10,11]} \cdot{ }^{210} \mathrm{~Pb}$ are naturally occurring radionuclides of the ${ }^{238} \mathrm{U}$ decay series with a 22.3 year. ${ }^{210} \mathrm{~Pb}$ is used to examine sediment mprocesses on a 100 year time scale. ${ }^{210} \mathrm{~Pb}$ is supplied by its effective parent ${ }^{226} \mathrm{Ra}$ in seawater and from ${ }^{222} \mathrm{Rn}$ in the atmosphere. The atmospheric source is produced as ${ }^{222} \mathrm{Rn}$, a shortlived (3.8 days) intermediate daughter of ${ }^{226} \mathrm{Ra}$, escapes from the earth's crust, decay to ${ }^{210} \mathrm{~Pb}$ and is deposited back to the ground. In most shallow water environment such as mangrove ecosystem, atmospheric input is the major source. In Malaysia, studies relating to mangroves are not well documented and only little information is known concerning the sedimentation of the mangrove forest ${ }^{[9,12]}$. Furthermore, geochemical

Corresponding Author: B.Y. Kamaruzzaman, Institute of Oceanography and Maritime Studies, International Islamic University Malaysia (IIUM), Jalan Istana, Bandar Indera Mahkota, 25200 Kuantan, Pahang, Malaysia 
studies of sediments from the Malaysian mangrove forests have received little attention and only limited studies have been done regarding their role in the process of sedimentation ${ }^{[9]}$. In view of the importance of the mangrove to various aspects of the environment, research on the sediment accretion as well as the sediment age were carried out.

\section{MATERIALS AND METHOD}

Sampling sites: The Kemaman-Chukai mangrove is located in the Kemaman district, inside one of the most extensive mangrove area (298.2 ha) on the east coast of Peninsular Malaysia (Fig. 1). The dominant species of mangrove tree found are Rhizopora sp., Avicennia sp. and Xylocarpus sp. The mangroves which are relatively undisturbed have been gazetted as a mangrove reserve forest by the Terengganu Forestry Department. The mangrove area lies on the southern bank of the Kemaman estuary, where both the Kemaman and Chukai rivers flow into. The tide floods the area twice daily as it is semi-diurnal with a mean range of $1.8 \mathrm{~m}$. In this study, a $20 \mathrm{~cm}$ sediment core from bothe Kemaman and Chukai mangrove were collected with a D-section core sampler from this area (Fig. 1) and was cut into segments of approximately $5 \mathrm{~cm}$ interval, labelled and stored in acid cleaned bottle for analysis.

Analytical methods for ${ }^{210} \mathrm{~Pb}$ : The samples were cut into segment approximately $2 \mathrm{~cm}$ interval using plastic knife and was transferred to petri disc. The samples were dried in an oven at $60^{\circ} \mathrm{C}$ to constants weights. To facilitate geochemical analysis the sample were ground into a fine powder using a pestle and mortar. The process of ${ }^{210} \mathrm{~Pb}$ excess dating method is divided into two process, digestion process and Po platting process ${ }^{[10,13]}$. The excess ${ }^{210} \mathrm{~Pb}$ in a different core was measured by the same procedure describes by

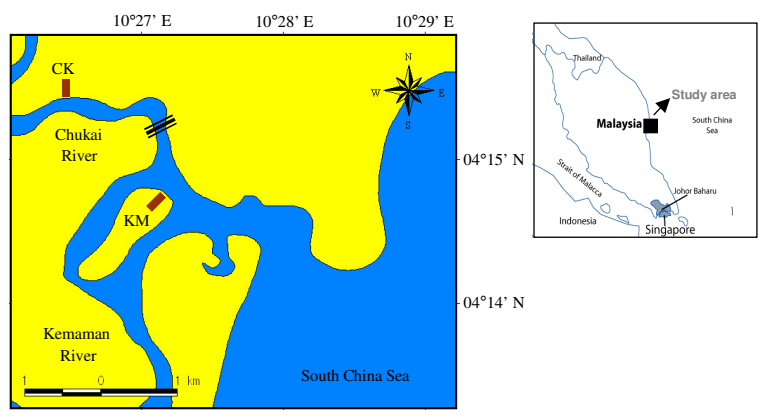

Fig. 1: Sampling location where 2 cores were collected at Kemaman (KM) and Chukai (CK) mangrove forest, Terengganu, Malaysia
Carpenter et $a l .{ }^{[10]}$ and Carpenter et al.$^{[13]}$. Activities of ${ }^{210} \mathrm{Po}$ along with the ${ }^{208} \mathrm{Po}$ tracer were measured by Alpha Spectrometry on a silicon surface barrier detector connected to a multi channel analyzer.

Data analysis: Total ${ }^{210} \mathrm{~Pb}$ activity was determined indirectly by the measurement of its alpha-emitting grand daughter nuclide, ${ }^{210} \mathrm{Po}^{[14]}$. Measurement of ratio ${ }^{210} \mathrm{Po}$ and ${ }^{209} \mathrm{Po}$ activity will provide an adequate figure of supported ${ }^{210} \mathrm{~Pb}$, as these two elements are assumed to be in equilibrium ${ }^{[15]}$. Subtracting of supported ${ }^{210} \mathrm{~Pb}$ from total ${ }^{210} \mathrm{~Pb}$ will determine unsupported ${ }^{210} \mathrm{~Pb}$. The activity of ${ }^{210} \mathrm{~Pb}$ is obtained by the formula below:

$$
\begin{aligned}
& \text { Activity }{ }^{210} \mathrm{Po}\left({ }^{210} \mathrm{~Pb}\right)=\mathrm{A}(\mathrm{dpm} / \mathrm{g}) \\
& =\frac{\text { Actual }{ }^{210} \mathrm{Po}\left({ }^{210} \mathrm{~Pb}\right)}{\text { Actual }^{209} \mathrm{Po}} \times{ }^{209} \mathrm{Po}(24.74 \mathrm{dpm} / \mathrm{g}) \times \frac{\text { tracer weight }{ }^{209} \mathrm{~Pb}(\mathrm{~g})}{\text { sample weight }(\mathrm{g})}
\end{aligned}
$$

Where:

$\mathrm{A}=\mathrm{A}_{\mathrm{o}} \mathrm{e}^{-\lambda \mathrm{t}}$ (equal to the accumulative residual unsupported ${ }^{210} \mathrm{~Pb}$ below the sediment age of $\mathrm{t}$ )

$\mathrm{A}_{\mathrm{o}}=\mathrm{A} / \mathrm{e}^{-\lambda \mathrm{t}}$ (equal to the total unsupported $\mathrm{Pb}$ in the sediment column)

$\lambda=\operatorname{Ln} 2 / \mathrm{t}_{1 / 2}=0.639$ (decay constant of ${ }^{210} \mathrm{~Pb}$ )

$\mathrm{T}_{1 / 2}=$ Half-life $(22.3$ years $)$

$\mathrm{t}=$ Depth $(\mathrm{cm}) /$ sedimentation rate in years

Inventories (I) of ${ }^{210} \mathrm{~Pb}$ (unsupported) are expressed in dpm-2 and were calculated according to Turekian ${ }^{[16]}$ :

$$
\mathrm{I}=\Sigma \mathrm{A}_{\mathrm{I}} \rho_{\mathrm{i}} \mathrm{h}_{\mathrm{i}}
$$

Where:

$\mathrm{A}_{\mathrm{i}}=$ The $^{210} \mathrm{~Pb}_{\mathrm{xs}}\left(\mathrm{dpm} \mathrm{g}^{-1}\right)$

$\rho_{\mathrm{i}}=$ The bulk density interval $\mathrm{i}\left(\mathrm{g} \mathrm{cm}^{-3}\right)$

$\mathrm{h}=$ The thickness of the interval $(\mathrm{cm})$

And finally the sedimentation rate can be calculated using the formula:

$$
\begin{aligned}
& A=A_{o} e^{-\lambda t} \\
& A=A_{o} e^{-\lambda(x / S)} \\
& \ln A=-(\lambda / S) x+\ln A_{o}
\end{aligned}
$$

Where:

$\mathrm{A}=$ Activity of excess ${ }^{210} \mathrm{~Pb}$ in the sediment at any depth

$\mathrm{A}_{\mathrm{o}}=$ Activity of excess ${ }^{210} \mathrm{~Pb}$ in the freshly deposited sediment at depth $=0$ (the sediment-water interface)

$\mathrm{S}=$ Sedimentation rate in $\mathrm{cm}_{\text {year }}{ }^{-1}$

$\lambda=$ Radioactive decay constant $(0.0311 /$ year $)$

$\mathrm{t}=$ Time in year 


\section{RESULTS AND DISCUSSION}

Figure 2 shows the activities of ${ }^{210} \mathrm{~Pb}_{\mathrm{xs}}$ were generally decreasing exponentially with depth. Some higher value of ${ }^{210} \mathrm{~Pb}$ activity on the surface might be caused by the settling particles which were basically derived from the atmosphere and land or from the older sediment issued from the resuspension process ${ }^{[17]}$. It is clear that ${ }^{210} \mathrm{~Pb}$ increases monotonically with depth, suggesting of the particulate scavenging ${ }^{[18]}$. The determination of average sedimentation rate is based on the assumption that the ${ }^{210} \mathrm{~Pb}_{\mathrm{xs}}$ is incorporated into the sediments with a constant rate ${ }^{[18]}$. As shown in Fig. 2, applying the formula as above, the sedimentation rate of Kemaman and Chukai mangrove forest were estimated to 1.11 and $0.94 \mathrm{~cm}_{\text {year }}{ }^{-1}$, respectively. The sedimentation rate was estimated by selecting the "bestcurve' from the establishment ${ }^{210} \mathrm{~Pb} \quad\left(\mathrm{dpm} \mathrm{g}^{-1}\right)$ distribution with depth. The $\mathrm{p}>0.01$ calculated from the statistical test, ANOVA two factor prove that the sedimentation rate among the study area are not significantly different. In this study, Chukai mangrove which is situated about $2 \mathrm{~km}$ from river mouth had the lowest accumulation rate while the highest sediment accumulation rate occurs at Kemaman mangrove which is situated near the river mouth. Rivers are believed to
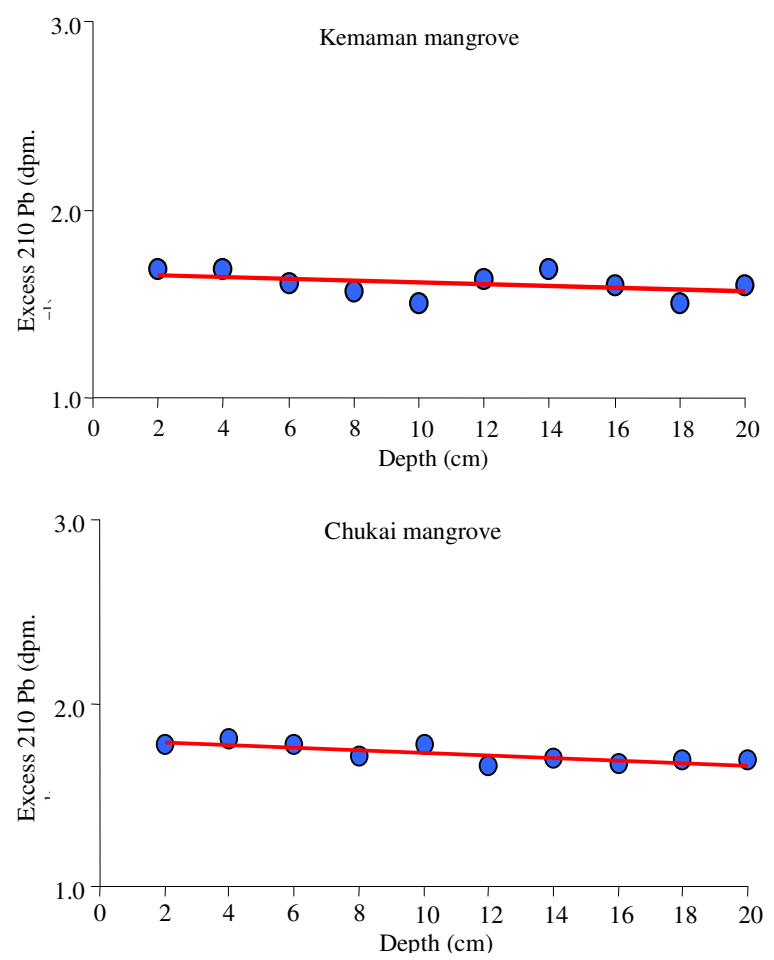

Fig. 2: ${ }^{210} \mathrm{~Pb}_{\text {excess }}$ distribution with depth in Terengganu mangrove forest be the dominant source of sediment to the KemamanChukai mangrove forest.

In Kemaman mangrove forest, the sedimentation rate obtained is consistent with the result obtained by Shabuddin et al. ${ }^{[5]}$, ranging from $0.64-1.46 \mathrm{~cm}_{\text {year }}{ }^{-1}$ with artificial horizontal marker method but is slightly higher compared with Kamaruzzaman et al. ${ }^{[19]}$ and Kamaruzzaman et al. ${ }^{[20]}, 0.68 \mathrm{~cm}_{\text {year }}{ }^{-1}$ with $^{230} \mathrm{Th}_{\mathrm{ex}}$ and ${ }^{230} \mathrm{Th}_{\mathrm{ex}}{ }^{232} \mathrm{Th}$ method. In comparison with other studies in Malaysia, sedimentation rate at KemamanChukai mangrove is slightly higher than Pahang mangrove, $0.65 \mathrm{~cm} \mathrm{year}^{-1[21]}$ and Johor mangrove, $0.84 \mathrm{~cm} \mathrm{year}{ }^{-1[22]}$ but lower compared to Matang mangrove, Perak ${ }^{[23]}, 1.08 \mathrm{~cm}^{\text {year }}{ }^{-1}$ using ${ }^{230} \mathrm{Th}_{\text {excess }}$ method.

From the sedimentation rates, ${ }^{210} \mathrm{~Pb}$ dating technique was used to determine the sediments age for the major estuarine mangrove forest in Terengganu region. Sediment age can be determined by dividing the sediment depth with sedimentation rate. The lower the sedimentation rate indicates the older age of sediment. Assuming that the sedimentation rate values are accurate, this implies that the sediments in the upper $100 \mathrm{~cm}$ at Kemaman-Chukai mangrove forest were deposited during the past 90 years. From the ANOVA test, the sediment age does not differ significantly among the study areas with $\mathrm{p}<0.05$. Briefly, Chukai mangrove which had the lowest sedimentation rate had the oldest mangrove with 106.6 years while the youngest mangrove, 90.2 years, occurred at Kemaman mangrove which had the highest sedimentation rate.

\section{CONCLUSION}

The sedimentation rates of Kemaman-Chukai mangrove forest, based on the ${ }^{210} \mathrm{~Pb}$ dating techniques were shown to be similar to the known local sea-level rise rate. The immobility of $\mathrm{Pb}$ in sediments was confirmed with stable ${ }^{210} \mathrm{~Pb}$ at the mangrove. It is suggested that the stable ${ }^{210} \mathrm{~Pb}$ is a powerful tracer in mangrove sediment studies on the determination of changing sedimentation rates, postdepositional mobilization and historical $\mathrm{Pb}$ sources.

\section{ACKNOWLEDGEMENT}

This research was conducted with joint funding from the Malaysia Ministry of Science and Technology under Fundamental Research Grant project number 57008. The authors wish to express their gratitude to Oceanography Laboratory, INOS and INOCEM teams for their invaluable assistance and hospitality throughout the sampling period. 


\section{REFERENCES}

1. Wolanski, E., Y. Mazda and P. Ridd, 1992. Mangrove Hydrodynamics. In: Tropical Mangrove Ecosystems, Robertson, A.I. and D.M. Alongi (Eds.). American Geophysical Union, Washington D.C., pp: 436-462.

2. Goldberg, E.D. and M. Koide, 1962. Geochonological studies of deep sea sediments by the ionium-thorium method. Geochim. Cosmochim. Acta, 26: 417-450.

3. Koide, M.A. Soutar and E.D. Goldberg. 1972. Marine geochronology with ${ }^{210} \mathrm{~Pb}$. Earth Planet. Sci. Lett., 14: 442-446.

4. Spenceley, A.P., 1982. Sedimentation patterns in a mangal on Magnetic Island near Townville, North Queensland, Australia. Singapore J. Trop. Geogr.,.3: 100-107.

5. Shahbuddin, S., H. Mohd Lokman, Y. Rosnan and T. Asano, 1998. Sediment accretion and variability of sedimentological characteristics of a tropical estuarine mangrove: Kemaman, terengganu, Malaysia. Mangroves and Salt Marshes, 55: 1-8.

6. Sharma, R., L.R. Gardner, W.S. Moore and M.S. Bollinger, 1987. Sedimentation and bioturbation in a salt marsh as revealed by ${ }^{210} \mathrm{~Pb}$, ${ }^{137} \mathrm{Cs}$ and ${ }^{7} \mathrm{Be}$ studies. Limnol. Oceanogr., 32: 313-326.

7. Lynch, J.C., J.R. Meriwether, B.A. McKee, F. Vera-Herrera and R.R. Twinlley, 1989. Recent accretion in mangrove ecosystems based on ${ }^{137} \mathrm{Cs}$ and ${ }^{210} \mathrm{~Pb}$. Estuaries, 4: 284-299.

8. Anderson, R.F., 1982. Concentration, vertical flux and remineralization of particulate uranium in seawater. Geochim. Cosmochim. Acta, 46: 1293-1299.

9. Kamaruzzaman, K.Y., H. Suhaimi, E.K. Teh, H.F. Leong, K.H. Soon and K.Y. Chong, 2000. The determination of ${ }^{230} \mathrm{Th}$ in the sediments: Sedimentation in the mangrove Forests of Pulau Sekeping, Kemaman, Terengganu. J. Ultra Sci. Phys. Sci., 13 (2): 239-245.

10. Carpenter, R., J.T. Bennett and M.L. Peterson, 1981. ${ }^{210} \mathrm{~Pb}$ activities in and fluxes to sediments of the Washington continental slope and shelf. Geochim. Cosmochim. Acta, 45: 1155-1172.

11. Crusius, J. and R.F. Anderson, 1991. Immobility of ${ }^{210} \mathrm{~Pb}$ in Black Sea sediments. Geochim. Cosmochim. Acta, 55: 327-333.

12. Kamaruzzaman, B.Y., 1999. Geochemistry of the marine sediments; Its paleoceanographic significance. Ph.D. Thesis, Hokkaido University, Japan.
13. Carpenter, R., M.L. Peterson and J.T. Bennett, 1982. Derived sediment accumulation and mixing rates for the greater Puget Sound region. Mar. Geol., 48: 135-140.

14. Zuo, Z., 1991. Dynamic behaviour of ${ }^{210} \mathrm{~Pb},{ }^{210} \mathrm{Po}$ and ${ }^{137} \mathrm{Cs}$ in Coastal and Environments, Geboren Te NanJing, China.

15. Gale, S.J., R.J. Haworth and P.C. Pisanu, 1995. The ${ }^{210} \mathrm{~Pb}$ chronology of the late holocene deposition in eastern Australian lake basin. Q. Sci. Rev., 14: 395-408.

16. Turekian, K.K. and K.K. Wadepohl, 1961. Distribution of the elements in some major units of the earth's crust. Bull. Geol. Soc. Am., 72: 175-192.

17. Miralles, J., O. Radakovitch and C. Aloisi, 2005. ${ }^{210} \mathrm{~Pb}$ sedimentation rate from the Northwestern Mediterranean margin. Elsevier Science. Mar. Geol., 216: 155-167.

18. Chung, Y., H.C. Chang and G.W. Hung, 2004. Particulate flux and ${ }^{210} \mathrm{~Pb}$ determined on the sediment trap and core samples from the northern South China Sea. Elsevier Science Ltd. Continental Shelf, 24: 673-691.

19. Kamaruzzaman, B.Y., K.H. Soon, M.L. Husain, I. Sulong and E.K. Teh, 2001. The sedimentary process in the mangrove forests of Pulau Che Wan Dagang, Kemaman, Terengganu. J. Biosci., 12 (1): 75-82.

20. Kamaruzzaman, B.Y., H. Suhaimi, E.K. Teh, H.F. Leong, K.H. Soon and K.Y. Chong, 2001. The determination of ${ }^{230} \mathrm{Th}$ in the sediments: Sedimentation in the mangrove frests of Pulau Sekeping, Kemaman, Terengganu. J. Ultra Sci. Phys. Sci., 13 (2): 239-245.

21. Kamaruzzaman, B.Y., H. Mohd Lokman, I. Sulong, B.T. Jamil and S. Hasrizal, 2003. Sediment accretion and trace metal concentrations in the surface sediment of Kuantan mangrove forest, Malaysia. Chem. Res. Commun., 16: 2-13.

22. Kamaruzzaman, B.Y., H.F. Leong, H.M. Lokman, I. Sulong and K.Y. Chong, 2002. The determination of ${ }^{230} \mathrm{Th}$ in the sediments: Sediment accretion in the mangrove forests of Tanjung Piai, Johore, Malaysia. Sains Malaysiana 31: 49-56.

23. Kamaruzzaman, B.Y., H. Suhaimi, N.A.M. Shazili, H.F. Leong, S. Hasrizal and N. Tahir, 2004. Sediment accretion and trace metal concentrations in the surface sediments of Matang mangrove forest, Malaysia. Malaysian J. Anal. Sci., 8 (1): 105-111. 